\title{
The absence of significant mutational events of the $p 53$ gene in the only two salivary gland tumors possessing radiation-related development risks, mucoepidermoid carcinoma and Warthin tumor
}

\author{
Mayumi Abé ${ }^{1}$, Satoshi Maruyama², Manabu Yamazaki ${ }^{1}$, Takanori Kobayashi², Kamal Al-Eryani', \\ Ahsan M. Shahidul ${ }^{1}$, Masayuki Tsuneki ${ }^{1}$, Mei Syafriadi', Takashi Saku ${ }^{1,2}$, Jun Cheng ${ }^{1}$ \\ ${ }^{1}$ Division of Oral Pathology, Department of Tissue Regeneration and Reconstruction, Niigata University Graduate School of Medical and \\ Dental Sciences, Niigata, Japan \\ ${ }^{2}$ Oral Pathology Section, Department of Surgical Pathology, Niigata University Hospital, Niigata, Japan
}

Abstract: Since the risks of development of salivary mucoepidermoid carcinoma and Warthin tumor have been significantly greater among atomic bomb survivors in a dose-dependent manner, the $p 53$ gene, an important proto-oncogene whose mutation has been related to radiation, was analyzed by DNA sequencing and immunohistochemistry in 37 cases of mucoepidermoid carcinoma collected from Niigata and Nagasaki and in 33 cases of Warthin tumor collected from Niigata. Immunohistochemically, $p 53$ gene products were heavily demonstrated in most of the tumor cell nuclei of mucoepidermoid carcinomas but not in Warthin tumors. Mucoepidermoid carcinomas had some point mutations (codons 136-137, 144, 232, 234, and 241) but their incidences among the samples were not significantly high (2.7\%-10.8\%). In contrast, three point mutations (codons 143, 151, and 229) were commonly found in the Warthin tumor cases $(80 \%-87 \%)$, but the former two mutations did not alter their amino acid composition. Thus, there were no $p 53$ mutations which were shared by the two tumors. However, the mutations at exon 5 of mucoepidermoid carcinomas were significantly higher in the cases from Nagasaki than those from Niigata, although their highest frequencies at most were around $10 \%$. The results suggest that point mutations of $p 53$ gene, as far as exons 5-7 were concerned, do not play any obviously important roles in the radiation-based tumorigenetic processes shared by mucoepidermoid carcinoma and Warthin tumor.

[Oral Med Pathol 2009; 13: 151-158 doi: 10.3353/omp.13.151]

Key words: atomic bomb, mucoepidermoid carcinoma, p53, salivary gland, Warthin tumor

Correspondence: Jun Cheng, Division of Oral Pathology, Department of Tissue Regeneration and Reconstruction, Niigata University Graduate School of Medical and Dental Sciences. 2-5274 Gakkocho-dori, Chuo-ku, Niigata 951-8514, Japan Phone: +81-25-227-2832, Fax: +81-25-227-0805, E-mail: jun@dent.niigata-u.ac.jp

\section{Introduction}

Little is known about the causes of salivary gland tumors. One of the most frequently investigated etiologic relationships concerns the association of Epstein-Barr viral (EBV) infections with lymphoepithelial carcinomas, although the pathogenetic mechanism of EBV still remains poorly understood (1-3). Another line of evidence reported for salivary gland tumorigenesis is the later effect of exposure to ionizing radiation by atomic bombs (4-7) and therapeutic radiation (8-13). Based on the survey of atomic bomb survivors in Hiroshima and Nagasaki, Japan, we have already found a causal role for ionizing radiation in salivary gland tumorigenesis, particularly in mucoepidermoid carcinomas and Warthin tumors, incidences of which were shown to be dependent on the radiation doses (14-15).

It has generally been accepted that mutational events in proto-oncogenes play important roles in human tumorigenesis. Among the proto-oncogenes, p53 gene has been extensively investigated for its functional changes due to alteration in various kinds of human experimental animal tumors (16-17). However, there has been a significant amount of information about $p 53$ mutations in salivary gland tumors, and their important role in their pathogeneses has been indicated (18-33). In addition, there have been a large number of reports on the relationship between frequent $p 53$ mutations and ultraviolet radiation-induced tumorigeneses of human skin squamous cell carcinoma (34) or experimental 
murine skin tumors (35-36).

However, it is unknown whether radiation-related salivary gland tumors have $p 53$ mutations. The aim of this study was to investigate mutational conditions of the $p 53$ gene in mucoepidermoid carcinomas and Warthin tumors, which have been closely related to radiation, in order to elucidate whether or not the developments of these two salivary tumors are dependent on the mutation of the $p 53$ gene.

\section{Materials and methods}

\section{Surgical materials}

Thirty-seven surgical specimens of mucoepidermoid carcinoma were collected from the surgical pathology files of the Department of Pathology, Faculty of Dentistry, Niigata University (21 cases) and Nagasaki University Hospital (16 cases) during a 34-year period from 1965 to 1998 without any selection procedures. The specimens from Nagasaki included those of atomic bomb survivors, although individual information about the bombing victims was not available due to personal information protection regulations. Thirty-three specimens of Warthin tumor were collected from only the Niigata University files during the same period. Surgical materials were fixed in $10 \%$ formalin and routinely processed for embedding in paraffin. Serial sections cut at $4 \mu \mathrm{m}$ were stained with hematoxylin-eosin (HE), and stained immunohistochemically with the antibody described below. The paraffin sections were also used for DNA extraction. For control studies, 5 surgical specimens of normal submandibular gland obtained in radical neck dissections were used in the same manner as described above. The experimental protocol for isolation and analyses of tumor cells was reviewed and approved by the Niigata University Graduate School of Medical and Dental Sciences Ethical Board.

\section{Antibody}

Bp53-11, a mouse monoclonal antibody ( $\left.\operatorname{IgG}_{2 a}\right)$ against human $p 53$ gene product, which recognizes the $\mathrm{NH}_{2}$-terminal domain, was purchased from Progen Biotechnik $\mathrm{GmbH}$ (Heidelberg, Germany).

\section{Immunohistochemistry}

The avidin-biotin peroxidase complex (ABC) technique, using biotinylated rabbit anti-mouse $\operatorname{IgG}$ (1:500, Dako, Glostrup, Denmark) and peroxidase-conjugated streptavidin complex (1:500, DAKO), was employed for immunohistochemical staining for the $p 53$ gene products (P53) (37). Briefly, sections were pretreated in $0.01 \mathrm{M}$ sodium citrate (pH 6.0) for $10 \mathrm{~min}$ at $120^{\circ} \mathrm{C}$ (wet autoclave) to disclose antigenic sites. The primary antibody was diluted to a concentration of $50 \mathrm{ng} / \mathrm{ml}$. For visualization of reaction products, sections were treated with 3.3'-diaminobenzidine in the presence of $0.05 \%$ hydrogen peroxide, and the sections were counterstained with hematoxylin. For the control sections, the primary antibody was replaced with normal mouse IgG. Prior to the reaction with the primary antibody, sections were incubated in $0.002 \%$ hydrogen peroxide in methanol to block endogenous peroxidase activities. Then, the sections were further incubated with $5 \%$ skim milk/PBS for $1 \mathrm{hr}$ at $37^{\circ} \mathrm{C}$ to block non-specific protein binding.

\section{Polymerase Chain Reaction (PCR)}

Total DNA was isolated from paraffin sections of mucoepidermoid carcinomas, Warthin tumors and normal submandibular gland tissues using the phenol-chloroform system. PCR was carried out in an Astec thermal cycler PC-800 (Astec Co., Ltd., Fukuoka, Japan) as follows: reaction products of the reverse transcription were diluted with $1 \times$ PCR buffer [ $50 \mathrm{mM} \mathrm{KCl}, 10 \mathrm{mM}$ Tris- $\mathrm{HCl}(\mathrm{pH} 8.5)$, $0.01 \%$ Triton $\mathrm{X}-100]$ to a final volume of $50 \mu \mathrm{l}$, which contained $100 \mathrm{ng}$ each of forward oligonucleotide primers and reverse primers for exons 5-7 of p53, additional dNTPs (final concentration of $0.2 \mathrm{mM}$ ), and 2.5 units of Taq DNA polymerase (Takara Bio Inc., Otsu, Japan). The PCR primers for human $p 53$ exon 5 were designed as follows: the sense primer was 5'-GTTTC TTTGC TGCCG TGTTC-3' (12972-12991), and the antisense primer was 3'-ACGGG TCCCA GGGGT CCGGA-5' (13275-13294). Those for exon 6 were 5'-TGGTT GCCCA GGGTC CCCAG-3' (13271-13290, forward) and 3'-ACCAA CAGTCA CCGGG AGG-5' (13475-13493, reverse). Those for exon 7 were 5'-CTTGC CACAG GTCTC CCCAA-3' (13941-13960, forward) and 3'-CGGTG AACGG TGGGA CGTGT-5' (14117-14136, reverse). The thermocycling protocol during 35 amplification cycles after denaturation at $94^{\circ} \mathrm{C}$ for $4 \mathrm{~min}$ was as follows: denaturation at $94^{\circ} \mathrm{C}$ for $1 \mathrm{~min}$; annealing at $60^{\circ} \mathrm{C}\left(62^{\circ} \mathrm{C}\right.$, exon 5) for $1 \mathrm{~min}$; extension at $72^{\circ} \mathrm{C}$ for $1 \mathrm{~min}$; and termination with a final cycle which involved annealing $\left(60^{\circ} \mathrm{C}\right.$ or $62^{\circ} \mathrm{C}$, exon 5 , for $\left.1 \mathrm{~min}\right)$ and extension $\left(72^{\circ} \mathrm{C}\right.$ for 7 $\mathrm{min})$. An exponential amplification for $p 53$ was confirmed in the 35 cycles. The amplified DNA fragments were analyzed by electrophoresis on $3 \%$ agarose gels (26).

\section{Direct Sequencing of PCR products for p53}

All PCR products were subjected to cycle sequencing by using Thermo Sequenase Core Sequencing Kits with 7-deaza-dGTP (GE Healthcare Ltd./Amersham, Buckinghamshire, UK). The sequence primers were synthesized based on the published data and labeled with Texas red at the 5'-end by using the 5' Oligonucleotide Texas Red Labeling Kit (Amersham). The labeled primers for $p 53$ exon 5 were 5'-TTCAA CTCTG TCTCC TTCCT-3' (forward); those for exon 6 were 5'-GCCTC TGATT CCTCA CTGAT-3' (forward); and those for exon 7 were 5'-CTTGC CACAG GTCTC CCCAA-3' (forward). One reaction mixture contained $3 \mu \mathrm{l}$ of premixes (appropriate nucleotides/reaction buffer/Thermo Sequenase DNA polymerase); $1 \mu \mathrm{l}$ of template PCR products, which were purified with GFX PCR DNA and Gel Band Purification Kits (Amersham); and $2 \mu \mathrm{l}$ $(2 \mathrm{pM})$ of Texas red-labeled primers. After denaturation at $95^{\circ} \mathrm{C}$ for $5 \mathrm{~min}$, the reaction mixture was placed on a thermal cycler for 25 cycles of denaturation at $95^{\circ} \mathrm{C}$ for $30 \mathrm{sec}$ and annealing/extension at $60^{\circ} \mathrm{C}$ for $30 \mathrm{sec}$. The reaction products were dissolved in $3 \mu$ l loading dye by vortexing, 
and then the mixture was concentrated with vacuum desiccators. Then, $3 \mu \mathrm{l}$ of samples for each lane were loaded on a gel (7\% Long Ranger (Nuseive FMC Bioproducts, Rocland, ME, USA)/6.1 M urea/1.2 × TBE buffer $(10 \mathrm{mM}$ Tris, $10 \mathrm{mM}$ boric acid, and $2 \mathrm{mM}$ EDTA)). The electrophoresis was performed in a fluorescent DNA sequencer (SQ-5500-S, Hitachi Ltd., Tokyo, Japan), and the sequencing data were analyzed by using the SQ-5500 analysis software, ver. 3.03 (Hitachi) $(2,38)$.

\section{Statistical analysis}

Statistical analysis was performed using Fisher's exact test for the incidental difference of p53 mutational events in mucoepidermoid carcinomas between Nagasaki and Niigata patients. A $P$-value of less than 0.05 was considered statistically significant.

\section{Results}

\section{Immunohistochemistry}

In mucoepidermoid carcinomas, differentiation of carcinoma cells varied among cases, showing two major directions of differentiation to mucous cells and squamous epithelial cells. Their carcinoma cell nests also varied from solid to glandular or large-cystic with mucous contents. Bizarre and hyperchromatic nuclei tended to be more often observed among squamous epithelial cells or mucous cells around cystic structures but not so frequently in regularly aligned glandular cells and so-called intermediate cells with clear cytoplasm. The stroma was partially hyaline, while most of it was fibrous with a recognizable amount of fibroblastic stromal cells (Fig. 1a). Immunohistochemically, positive staining for P53 was obtained in most of the cases examined. The reaction products were restricted to tumor cell nuclei. In particular, atypical nuclei showed stronger staining intensities. However, extremely bizarre nuclei did not show positive reactions for P53 (Fig.1b). All of the examined cases showed the same tendency.

The histology of Warthin tumors was characterized by glandular structures composed of a two-cell layer of eosinophilic ductal cells with oncocytic appearances and a dense lymphocytic stroma scattering lymphoid follicles. The glandular structures were often distended with serous contents with lines of tumor cells infolded in a complicated

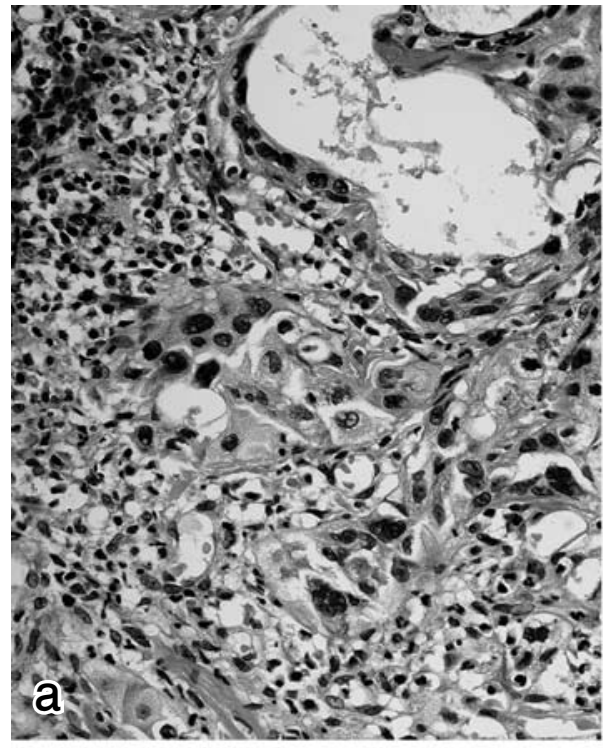

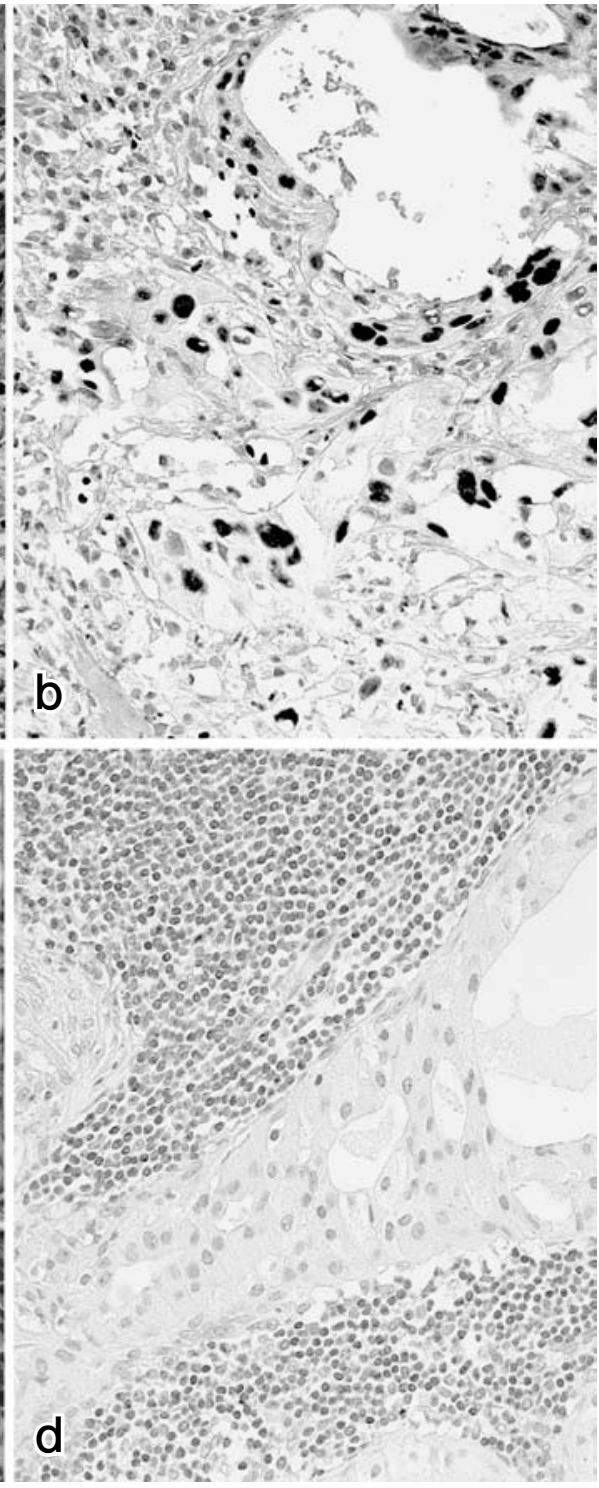

Fig. 1. Immunohistochemical localization of P53 in mucoepidermoid carcinoma and Warthin tumor. (a, b) Mucoepidermoid carcinoma, (c d) Warthin tumor. (a,c) Hematoxylin and eosin (HE) stain, (b, d) immunoperoxidase stain for P53, hematoxylin counterstain, $\times 180$. In mucoepidermoid carcinoma, P53 was localized within nuclei of carcinoma cells. The stainings were more intensive in bizarre nuclei, while some of them were not positive. In Warthin tumor, P53 was not demonstrated in tumor cells nor in stromal cells. 
exon 5

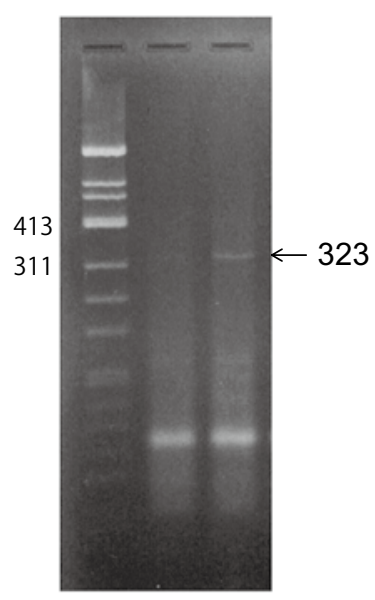

exon 6

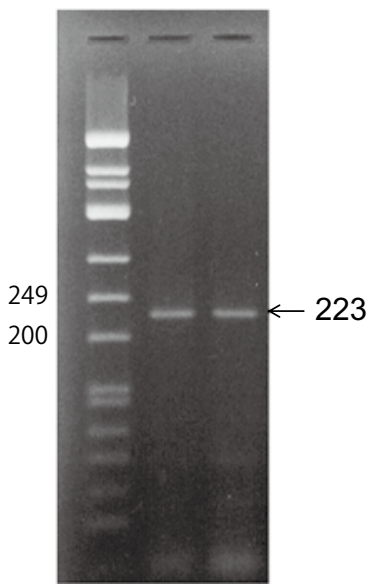

exon 7

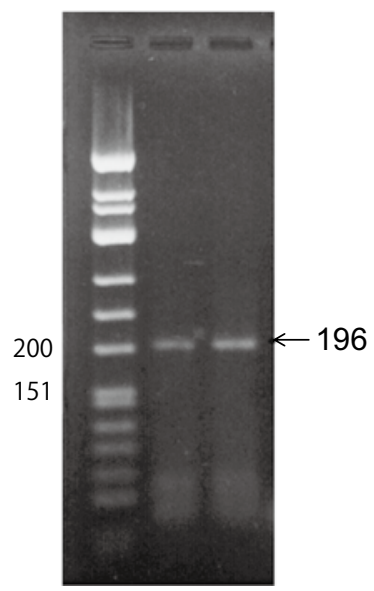

Fig. 2. PCR-products for $p 53$ gene, exons 5, 6 and 7 in mucoepidermoid carcinoma. (left) Exon 5, 323-bp, (middle) exon 6, 223-bp, (right) exon 7, 196-bp. Left lanes in each column, molecular weight standards. PCR products of three exons were successfully obtained from DNA samples extracted from paraffin sections of formalin-fixed surgical materials. manner, resulting in their papillary appearance (Fig. 1c). Immunohistochemically, tumor cells did not show any discernible staining for P53. Stromal lymphoid cells were not positive, either (Fig. 1d).

The results indicated that $p 53$ gene products were overexpressed in mucoepidermoid carcinoma cells but not in Warthin tumor cells. This demonstrated that there seemed to be a significant difference in P53 turnover between benign and malignant tumors.

\section{PCR and sequencing}

Based on the histological evidence that over-expression of p53 gene products took place in mucoepidermoid carcinomas, we carried out PCR amplification of the $p 53$ gene fragments from genomic DNA extracts of paraffin sections which were serial to those used for immunohistochemistry. Five to twenty sections, depending on the size, were dewaxed and extracted in a plastic tube. Total DNA yields averaged about $16 \mu \mathrm{g}$ per tube. Under the PCR condition described in Materials and Methods, exons 5 to 7 were successfully amplified as shown in electrophoresis images of Fig. 2. Single clear bands with molecular masses of $323 \mathrm{bp}, 223 \mathrm{bp}$, and $196 \mathrm{bp}$ were obtained for exons 5, 6, and 7, respectively (Fig. 2).

For direct sequencing of the PCR products, they were further purified with GFX PCR DNA and Gel Band Purification Kits. The purified DNA samples of exons 5 to 7 were applied for sequenase reactions and sequencing procedures. The results from mucoepidermoid carcinoma samples are summarized in Table 1. In exon 5, two point mutations were found. They were CAA CTG $\rightarrow$ CA $\underline{\text { GTG }}$ at codons $136-137$ and $\mathrm{CAG} \rightarrow$ TAG at codon 144 . These mutations led to changes in the amino acid sequence from Gln-Leu to Gln-Val and Gln to a stop codon, respectively. The replacement of $\mathrm{C}$ with $\mathrm{T}$ at codon 144 was not always caused by complete deletion of $\mathrm{C}$ but by double small peaks of $\mathrm{C}$ and $\mathrm{T}$, indicating a heterogeneous mutation at this point. The incidence of the former was $2.7 \%$ among 37 cases and that of the latter was $10.8 \%$. There were no mutational events in exon 6 . In exon 7 , three point mutations were revealed from mucoepidermoid carcinoma samples. They were ATC $\rightarrow$ A $\underline{\text { GC }}$ at codon 232, TAC $\rightarrow$ T $\underline{\text { GC }}$ or $\underline{\mathrm{CAC}}$ at codon 234, and TCC TGC $\rightarrow$ CC TGC AGT at codon 241-242. When translated into amino acids, they should have altered from Ile to Ser (3.2\%), from Tyr to Cys or His (6.5\%), and from Ser-Cys to nonsense sequences starting with Pro-Ala (3.2\%). The replacement of A with $\mathrm{G}$ at codon 234 was not always caused by complete deletion of A, indicating a heterogeneous mutation at this point. All of these mutations were severe enough to affect their translation into amino acids. However, their incidence among mucoepidermoid carcinomas was not conspicuous. In addition, these mutations were not always $\mathrm{C} \rightarrow \mathrm{T}$ and $\mathrm{CC} \rightarrow$ TT transitions, which were considered to be UV radiation specific $(34,36)$.

Table 1. p53 mutations in 37 cases of mucoepidermoid carcinoma

\begin{tabular}{|c|c|c|c|c|}
\hline Exon & Codon & Bases (Amino acid) & Mutation & Frequency (\%) \\
\hline 5 & $136-137$ & $\begin{array}{l}\text { CAA CTG } \\
\text { (Gln Leu) }\end{array}$ & $\begin{array}{l}\text { CAG } \underline{G T G} \\
\text { (Gln Val) }\end{array}$ & 2.7 \\
\hline 5 & 144 & $\begin{array}{l}\text { CAG } \\
\text { (Gln) }\end{array}$ & $\begin{array}{l}\text { TAG } \\
\text { (stop) }\end{array}$ & 10.8 \\
\hline 7 & 232 & $\begin{array}{l}\text { ATC } \\
\text { (Ile) }\end{array}$ & $\begin{array}{l}\text { AGC } \\
\text { (Ser) }\end{array}$ & 3.2 \\
\hline 7 & 234 & $\begin{array}{l}\text { TAC } \\
\text { (Tyr) }\end{array}$ & $\begin{array}{l}\text { T } \underline{G C} / \mathrm{CAC} \\
\text { (Cys) / (His) }\end{array}$ & 6.5 \\
\hline 7 & 241 & $\begin{array}{l}\text { TCC TGC } \\
\text { (Ser Cys) }\end{array}$ & $\begin{array}{l}\text { _CC TGC AGT } \\
\text { (Pro Ala .........) }\end{array}$ & 3.2 \\
\hline
\end{tabular}


Table 2. p53 mutations in 33 cases of Warthin tumor

\begin{tabular}{|c|c|c|c|c|}
\hline Exon & Codon & Bases (Amino acid) & Mutation & Frequency $(\%)$ \\
\hline 5 & 143 & $\begin{array}{l}\text { GTG } \\
\text { (Val) }\end{array}$ & $\begin{array}{l}\mathrm{GTC} / \mathrm{GTA} \\
\text { (Val) / ( Val) }\end{array}$ & 87 \\
\hline 5 & 151 & $\begin{array}{l}\mathrm{CCC} \\
\text { (Pro) }\end{array}$ & $\begin{array}{l}\mathrm{CCT} / \mathrm{CC} \underline{\mathrm{A}} \\
\text { (Pro) / (Pro) }\end{array}$ & 87 \\
\hline 7 & 229 & $\begin{array}{l}\text { TGT } \\
\text { (Cys) }\end{array}$ & $\begin{array}{l}\text { AGT / GGT } \\
\text { (Ser) / (Gly) }\end{array}$ & 80 \\
\hline
\end{tabular}

In Warthin tumors, two point mutations were found from exon 5. They were located in codons 143 and 151 . In the latter, CCC was changed to CCT or CC․․ In the former, GTG was altered to GTC or GTA, and their incidences were equally $87 \%$ of 33 cases. The replacement of $G$ with $C$ at codon 143 was not always caused by complete deletion of $\mathrm{G}$ but by the presence of a small $\mathrm{G}$ peak, indicating that the mutation was heterogeneous. Similar to mucoepidermoid carcinomas, there was no exon 6 mutation in Warthin tumors. In exon 7 , there was a highly coincidental (80\%) mutation at codon 229, in which TGT (Cys) was replaced with AGT (Ser) or GGT (Gly). Since the replacement of T with $\mathrm{G}$ at codon 229 was associated with incomplete deletion of $\mathrm{T}$, the mutations were regarded as heterogeneous. Although the coincidence of these point mutations was quite high, two of the three did not lead to any change in the amino acid sequence. The results from Warthin tumor samples are summarized in Table 2.

Mutational events of $p 53$ gene in mucoepidermoid carcinoma cases revealed as above were compared between patients from Niigata and Nagasaki, because the cases from Nagasaki should have included those from atomic bomb survivors. Since personal information about atomic bomb radiation doses was unfortunately not obtained, the comparison itself was not always worth performing. However, as shown in Table 3, all of the mutations in exon 5 were found in 4 patients from Nagasaki only. The mutations in exon 7 were found in 2 patients from Nagasaki and 1 from Niigata. The incidence of these point mutations was only $8-10 \%$ of the cases, so it was unlikely that $p 53$ mutations played key roles in the pathogenesis of mucoepidermoid carcinoma. However, when patients from Nagasaki and Niigata were compared, the incidence of mutational events in exon 5 of the $p 53$ gene was significantly higher $(P<0.05)$ in patients from Nagasaki compared to those from Niigata. In regard to exon 7, no significant difference was demonstrated between the two areas.

\section{Discussion}

In the present study, the over-expression of $p 53$ gene products was only obvious in tumor cells of mucoepidermoid carcinoma but not in those of Warthin tumor. This result was not surprising, because the over-expression of $p 53$ has been reported to be specific to lesions with cellular proliferation or malignancy (18-25). The over-expression of P53 in mucoepidermoid carcinomas has been well documented with its frequencies ranging from $53 \%$ to $67 \%(25,28$, 30-31), while the sequencing data of the $p 53$ gene have been rather limited, showing some sporadic point mutations (27, $29,32-33)$. In physiological conditions, $p 53$ gene products are degraded soon after they are targeted to nuclei (39), hence, it is usually hard to detect P53 within a cell by conventional immunohistochemical methods. The intensive staining for P53 within nuclei of mucoepidermoid carcinoma cells thus indicates that the cells produced too much protein in comparison to those degraded by its lyases, which were within normal levels of expression. Another possible explanation is that the over-expressed P53 are mutant forms which are resistant to proteolytic cleavages. Thus, it was expected that we would analyze the $p 53$ gene for mutations in mucoepidermoid carcinoma specimens with enhanced expression of its gene products, although it was uncertain whether the over-expressed $p 53$ was functional in $\mathrm{G}_{1}$ arrest of the cell cycling as well as apoptotic pathways (40).

There have been no documents in the literature describing mutational events of the $p 53$ gene in Warthin tumor. In the present study, however, we found $p 53$ mutational points in Warthin tumor cases which were highly shared among the sample group, although those point mutations did not affect the amino acid translation so much, indicating that they were just genetic polymorphisms. As shown in the sequencing

Table 3. Comparison of incidence of p53 mutations in mucoepidermoid carcinomas between patients from Nagasaki and Niigata $(\%)$

\begin{tabular}{ccccc}
\hline Patients from & exon 5 & exon 6 & exon 7 & Total \\
\hline Nagasaki & 25 & 0 & 15.4 & 31.3 \\
$(\mathrm{n}=16)$ & $(4)$ & $(0)$ & $(2)$ & $(5)$ \\
Niigata & 0 & 0 & 5.6 & 4.8 \\
$(\mathrm{n}=21)$ & $(0)$ & $(0)$ & $(1)$ & $(1)$ \\
\hline Total & 10.8 & 0 & 23.1 & 16.2 \\
$(\mathrm{n}=37)$ & $(4)$ & $(0)$ & $(3)$ & $(6)$ \\
\hline
\end{tabular}


profiles, the mutations were not always homogenous but were heterogeneous in many of the instances. The clinical features of Warthin tumors are quite different from those of other types of salivary gland tumor. They often show bilaterally synchronous as well as metachronous development or unilateral multiple developments (41). These developmental characteristics indicate some background of reactive histogenesis, including delayed hypersensitivity or inflammation in Warthin tumors $(14,42)$. The present data indicate a possibility that immunological or inflammatory stimuli tend to be associated with some intrinsic background such as p53 gene polymorphisms in the pathogenesis of Warthin tumor.

Together with Warthin tumors, mucoepidermoid carcinomas have been shown to be related to radiation in their pathogenesis (14-15). Therefore, these two tumors were simply expected to share certain common gene mutational backgrounds caused by radiation. However, in contrast to the Warthin tumor data of silent mutations, all of the point mutations in mucoepidermoid carcinoma cases were missense, leading to changes in the amino acid sequence of P53, but each of their frequencies was much lower than those found in Warthin tumors. The present results clearly showed that there was neither a common feature of genetic mutation between the two tumors nor UV-radiation specific mutations such as $\mathrm{C} \rightarrow \mathrm{T}$ and $\mathrm{CC} \rightarrow$ TT transitions $(34,35)$, as far as exons 5-7 were concerned. In addition, the result that obviously atypical mucoepidermoid carcinoma cells were not always immunopositive for P53 was noted. This may have been due to the mutated amino acid sequences of the $\mathrm{P} 53 \mathrm{NH}_{2}$-terminal region, which could not be recognized by the antibody, Bp53-11 (43).

Different from the myelogenous or thyroid neoplasms that atomic bomb survivors suffered from soon after the Hiroshima-Nagasaki bombings (5) or the Chernobyl accident (44), direct and severe gene mutations after high dose radiation exposure have not been considered to be causative of salivary mucoepidermoid carcinomas and Warthin tumors. Our previous studies showed that these tumors developed after long intervals since irradiation by the atomic bombs, although their occurrences were highly dependent on the radiation doses of the patients (14-15). These two tumors are hence typical but rare examples of human diseases caused by delayed gene alterations due to radiation-induced genetic instability (45-46). It is unknown whether the molecular mechanisms for such gene alterations develop after a long interval from irradiation events. However, recent in-vitro studies have demonstrated several lines of evidence for the delayed gene mutation. Delayed lethal gene mutations were confirmed in Chinese hamster ovary cells or BALB/3T3 cells, which had undergone 30 mean population doublings after X-ray irradiation (47). Carls and Schiestl reported deletion of one specific DNA fragment in mice whose parents were irradiated (48), indicating that a high level of genetic instability was caused by a mutator phenotype transmitted through many cell divisions or over generations. More recently, chromosomal instability has also been shown in atomic bomb survivors with leukemia (49). We have also paid attention to the translocation $\mathrm{t}(11 ; 19)(\mathrm{q} 21 ; \mathrm{p} 13)$, which had been found in mucoepidermoid carcinoma and rarely in Warthin tumor, as well (50). However, recently, Fehr et al have demonstrated that this translocation was not significant in the pathogenesis of Warthin tumors (51). Further investigations on the detailed molecular basis for genetic instability are necessary for a better understanding of the molecular basis of radiation-induced tumorigenesis shared by mucoepidermoid carcinoma and Warthin tumor.

The frequency and the severity of the $p 53$ mutations in mucoepidermoid carcinomas were not so high, although they were greater than those in Warthin tumor. However, their incidence in mucoepidermoid carcinoma among the patients from Nagasaki, which contained atomic bomb survivors, was higher than that of the patients from Niigata. Unfortunately, it was not possible to collate those mutations with the radiation doses among the patients from Nagasaki in the present study. However, the present data suggest that a history of irradiation predisposes $p 53$ gene mutations. A number of studies have dealt with the relationship between p53 mutations andultravioletradiation-induced tumorigenesis of experimental murine skin tumors $(35-36,52)$ and human cancers $(34,53)$. Although the $p 53$ gene mutations in exons 5-7 did not seem to be important in the pathogeneses of mucoepidermoid carcinoma and Warthin tumor in the present study, the definite enhancement of P53 expression in mucoepidermoid carcinoma indicates at least a metabolic disturbance of $p 53$ gene products in mucoepidermoid carcinoma cells. It is therefore suggested that some delayed gene mutations caused by radiation took place somewhere in the upstream of $p 53$ cascades, which stimulates overexpression of P53, although it still remains unknown whether the over-expressed P53 participate in the carcinogenesis of mucoepidermoid carcinomas.

\section{Acknowledgments}

The authors are grateful to Dr. Hideo Miyazaki, Niigata University, for his valuable suggestion to our statistical study. They also thank Dr. Nobuo Tsuda, Nagasaki University Hospital, for supplying the paraffin blocks of mucoepidermoid carcinoma. This work was supported in part by Grants-in-Aid for Scientific Research from the Japan Society for the Promotion of Science and from the Ministry of Education, Culture, Sports, Science and Technology, Japan.

\section{References}

1. Jen KY, Cheng J, Li J, et al. Mutational events in LMP1 gene of Epstein-Barr virus in salivary gland lymphoepithelial carcinomas. Int J Cancer 2003; 105: 654-60.

2. Nagao T, Ishida Y, Sugano I, et al. Epstein-Barr virusassociated undifferentiated carcinoma with lymphoid stroma of salivary gland in Japanese patients. Comparison with benign lymphoepithelial lesion. Cancer 1996; 78: 695-703.

3. Saku T, Cheng J, Jen KY, et al. Epstein-Barr virus infected lymphoepithelial carcinomas of the salivary gland in the 
Russia-Asia area: a clinicopathologic study of 160 cases. Arch Pathol 2003; 65: 35-9.

4. Belsky JL, Tachikawa K, Cihak RW, Yamamoto T. Salivary gland tumors in atomic bomb survivors, HiroshimaNagasaki, 1957 to 1970. JAMA 1972; 219: 864-8.

5. Belsky JL, Takeichi N, Yamamoto T, et al. Salivary gland neoplasms following atomic radiation: Additional cases and reanalysis of combined data in a fixed population, 1957-1970. Cancer 1975; 35: 555-9.

6. Ohkita T, Takahashi N, Takeichi N, Hirose F. Prevalence of leukemia and salivary gland tumours among Hiroshima Atomic Bomb Survivors. In: Late Biological Effects of Ionizing Radiation. Volume 1. International Atomic Energy Agency, Vienna, 1978; 71-81.

7. Takeichi N, Hirose F, Yamamoto H, Ezaki H, Fujikura T. Salivary gland tumors in atomic bomb survivors, Hiroshima, Japan. II. Pathologic study and supplementary epidemiologic observations. Cancer 1983; 52: 377-85.

8. Ju DM. Salivary gland tumors occurring after radiation of the head and neck area. Am J Surg 1968; 116: 518-23.

9. Katz AD, Preston-Martin S. Salivary gland tumors and previous radiotherapy to the head or neck. Report of a clinical series. Am J Surg 1984; 147: 345-8.

10. Palmer JA, Mustard RA, Simpson WJ. Irradiation as an etiologic factor in tumours of the thyroid, parathyroid and salivary glands. Can J Surg 1980; 23: 39-42.

11. Preston-Martin S, White SC. Brain and salivary gland tumors related to prior dental radiography: implications for current practice. J Am Dent Assoc 1990; 120: 151-8.

12. Shore-Freedman E, Abrahams C, Recant W, Schneider AB. Neurilemmomas and salivary gland tumors of the head neck following childhood irradiation. Cancer 1983; 51: 2159-63

13. Spitz MR, Batsakis JG. Major salivary gland carcinoma. Descriptive epidemiology and survival of 498 patients. Arch Otolaryngol 1984; 110: 45-9.

14. Land CE, Saku T, Hayashi Y, et al. Incidence of salivary gland tumors among atomic bomb survivors, 1950-1987. Evaluation of radiation-related risk. Radiat Res 1996; 146: 28-36.

15. Saku T, Hayashi Y, Takahara O, et al. Salivary gland tumors among atomic bomb survivors, 1950-1987. Cancer 1997; 79: $1465-75$.

16. Brash DE. Roles of the transcription factor $\mathrm{p} 53$ in keratinocyte carcinomas. Br J Dermatol 2006; 154 Suppl 1 : 8-10.

17. Lubet RA, Zhang Z, Wiseman RW, You M. Use of p53 transgenic mice in the development of cancer models for multiple purposes. Exp Lung Res 2000; 26: 581-93.

18. Alves FA, Pires FR, De Almeida OP, Lopes MA, Kowalski LP. PCNA, Ki-67 and p53 expressions in submandibular salivary gland tumours. Int J Oral Maxillofac Surg 2004; 33: $593-7$.

19. Arida M, Barnes EL, Hunt JL. Molecular assessment of allelic loss in Warthin tumors. Mod Pathol 2005; 18: 964-8

20. Deguchi H, Hamano H, Hayashi Y. c-myc, ras and p53 expression in pleomorphic adenoma and its malignant form of the human salivary glands. Acta Pathol Jpn 1993; 43: 413-22.
21. Gallo O, Franchi A, Bianchi S, Boddi V, Gianelli E, Alajmo E. p53 oncoprotein expression in parotid gland carcinoma is associated with clinical outcome. Cancer 1995; 75: 2037-44.

22. Genetzakis M, Gomatos IP, Georgiou AN, et al. BCL-2, p53 and HLA-DR antigen expression in surgically treated parotid cancer patients. Eur Arch Otorhinolaryngol 2009; 266: 417-24.

23. Ishii K, Nakajima T. Evaluation of malignant grade of salivary gland tumors: studies by cytofluorometric nuclear DNA analysis, histochemistry for nucleolar organizer regions and immunohistochemistry for p53. Pathol Int 1994; 44: 287-96.

24. Kärjä VJ, Syrjänen KJ, Kurvinen AK, Syrjänen SM Expression and mutations of p53 in salivary gland tumours. J Oral Pathol Med 1997; 26: 217-23.

25. Lee EJ, Kim J, Lee SA, et al. Characterization of newly established oral cancer cell lines derived from six squamous cell carcinoma and two mucoepidermoid carcinoma cells. Exp Mol Med 2005; 37: 379-90.

26. Li X, Tsuji T, Wen S, Sobhan F, Wang Z, Shinozaki F. Cytoplasmic expression of $\mathrm{p} 53$ protein and its morphological features in salivary gland lesions. J Oral Pathol Med 1995; 24: 201-5.

27. Matizonkas-Antonio LF, de Mesquita RA, de Souza SC, Nunes FD. TP53 mutation in salivary gland neoplasms. Braz Dent J 2005; 16: 162-6.

28. Nordkvist A, Röijer E, Bang G, et al. Expression and mutation patterns of P53 in benign and malignant salivary gland tumors. Int J Oncol 2000; 16: 477-83.

29. Ohki K, Kumamoto H, Ichinohazama R, et al. Genetic analysis of DNA microsatellite loci in salivary gland tumours: comparison with immunohistochemical detection of hMSH2 and p53 proteins. Int J Oral Maxillofac Surg 2001; 30: 538-44.

30. Papadaki H, Finkelstein SD, Kounelis S, Bakker A, Swalsky PA, Kapadia SB. The role of p53 mutation and protein expression in primary and recurrent adenoid cystic carcinoma. Hum Pathol 1996; 27: 567-72.

31. Soini Y, Kamel D, Nuorva K, Lane DP, Vähäkangas K, Pääkkö P. Low p53 protein expression in salivary gland tumours compared with lung carcinomas. Virchows Archiv A Pathol Anat Histopathol 1992; 421: 415-20.

32. Suzuki T. p53 abnormality in salivary gland carcinoma and its relation to tumor DNA aneuploidy and AgNOR. Nippon Jibiinkoka Gakkai Kaiho 1994; 97: 2279-86.

33. Yamamoto Y, Kishimoto Y, Wistuba II, et al. DNA analysis at p53 locus in carcinomas arising from pleomorphic adenomas of salivary gland: Comparison of molecular study and p53 immunostaining. Pathol Int 1998; 48 265-72.

34. Brash DE, Rudolph JA, Simon JA, et al. A role for sunlight in skin cancer: UV-induced p53 mutations in squamous cell carcinoma. Proc Natl Acad Sci USA 1991; 88: 10124-8.

35. Benjamin CL, Ullrich SE, Kripke ML, Ananthaswamy HN p53 tumor suppressor gene: a critical molecular target for UV induction and prevention of skin cancer. Photochem Photobiol 2008; 84: 55-62.

36. Kanjilal S, Pierceall WE, Cummings KK, Kripke ML, Ananthaswamy HN. High frequency of p53 mutations in 
ultraviolet radiation-induced murine skin tumors: evidence for strand bias and tumor heterogeneity. Cancer Res 1993; 53: $2961-4$.

37. Fisher CJ, Gillett CE, Vojtêsek B, Barnes DM, Millis RR. Problems with p53 immunohistochemical staining: the effect of fixation and variation in the methods of evaluation. Br J Cancer 1994; 69: 26-31.

38. Levine AJ. The p53 tumor suppressor gene and gene product. Princess Takamatsu Symp 1989; 20: 221-30.

39. Steele RJ, Thompson AM, Hall PA, Lane DP. The p53 tumour suppressor gene. Br J Surg 1998; 85: 1460-7.

40. Moll UM, Schramm LM. p53 - an acrobat in tumorigenesis. Crit Rev Oral Biol Med 1998; 9: 23-37.

41. Gnepp DR, Schroeder W, Heffner D. Synchronous tumors arising in a single major salivary gland. Cancer 1989; 63: 1219-24.

42. Teymoortash A, Werner JA. Tissue that has lost its track: Warthin's tumour. Virchows Arch 2005; 446: 585-8.

43. Stephen CW, Helminen P, Lane DP. Characterisation of epitopes on human p53 using phage-displayed peptide libraries: insights into antibody-peptide interactions. $J \mathrm{Mol}$ Biol 1995; 248: 58-78.

44. Rybakov SJ, Komissarenko IV, Tronko ND, et al. Thyroid cancer in children of Ukraine after the Chernobyl accident. World J Surg 2000; 24: 1446-9.

45. Niwa O. Delayed effects and induction of genetic instability by radiation. J Toxicol Sci 1996; 21: 61-3.
46. Plumb M, Cleary H, Wright E. Genetic instability in radiation-induced leukemias: mouse models. Int J Radiat Biol 1998; 74: 711-20.

47. Little JB, Gorgojo L, Vetrovs H. Delayed appearance of lethal and specific gene mutations in irradiated mammalian cells. Int J Radiat Oncol Biol Phys 1990; 19: 1425-9.

48. Carls N, Schiestl RH. Effect of ionizing radiation on transgenerational appearance of $\mathrm{p}(\mathrm{un})$ reversions in mice. Carcinogenesis 1999; 20: 2351-4.

49. Nakanishi M, Tanaka K, Shintani T, Takahashi T, Kamada N. Chromosomal instability in acute myelocytic leukemia and myelodysplastic syndrome patients among atomic bomb survivors. J Radiat Res (Tokyo) 1999; 40: 159-67.

50. Enlund F, Behboudi A, Andrén Y, et al. Altered Notch signaling resulting from expression of a WAMTP1-MAML2 gene fusion in mucoepidermoid carcinomas and benign Warthin's tumors. Exp Cell Res 2004; 292: 21-8.

51. Fehr A, Röser K, Belge G, Löning T, Bullerdiek J. A closer look at Warthin tumors and the $\mathrm{t}(11 ; 19)$. Cancer Genet Cytogenet 2008; 180: 135-9.

52. Jiang W, Ananthaswamy HN, Muller HK, Kripke ML. p53 protects against skin cancer induction by UV-B radiation. Oncogene 1999; 18: 4247-53.

53. Ohnishi K, Nagata Y, Takahashi A, Taniguchi S, Ohnishi T. Effective enhancement of X-ray-induced apoptosis in human cancer cells with mutated p53 by siRNA targeting XIAP. Oncol Rep 2008; 20: 57-61. 